\title{
Streptomyces griseus
}

National Cancer Institute

\section{Source}

National Cancer Institute. Streptomyces griseus. NCI Thesaurus. Code C86813.

A species of aerobic, Gram positive, filamentous bacteria in the phylum Actinobacteria.

This species is spore forming, yellow to orange colored, elastase and hydrolase positive and produces streptomycin. S. griseus is not a known pathogen. 